\title{
PLKI as a potential prognostic marker of gastric cancer through MEK-ER K pathway on PDTX models [Corrigendum]
}

\author{
Dang SC, Fan YY, Cui L, Chen JX, Qu JG, Gu M. \\ Onco Targets Ther. 2018;11:6239-6247.
}

On page 6239,2 nd affiliation was listed as "Zhenjiang Integrative Medicine Hospital, Zhenjiang, Jiangsu Province, People's Republic of China" however it should have been "Zhenjiang Hospital of Traditional Chinese and Western Medicine, Zhenjiang, Jiangsu, People's Republic of China”
On page 6239, Correspondence address was listed as "Zhenjiang Integrative Medicine Hospital, Zhenjiang, Jiangsu Province, People's Republic of China" however it should have been "Zhenjiang Hospital of Traditional Chinese and Western Medicine, Zhenjiang, Jiangsu 212001, People's Republic of China".

\section{Publish your work in this journal}

OncoTargets and Therapy is an international, peer-reviewed, open access journal focusing on the pathological basis of all cancers, potential targets for therapy and treatment protocols employed to improve the management of cancer patients. The journal also focuses on the impact of management programs and new therapeutic agents and protocols on patient perspectives such as quality of life, adherence and satisfaction. The manuscript management system is completely online and includes a very quick and fair peer-review system, which is all easy to use. Visit http://www.dovepress.com/testimonials.php to read real quotes from published authors 